\title{
Makna Wayang Golek si Cepot pada Masyarakat Sunda Milenial dan Generasi Z
}

\author{
Andrew Limelta, Sinta Paramita \\ andrew.limelta@gmail.com, sintap@fikom.untar.ac.id \\ Fakultas Ilmu Komunikasi Universitas Tarumanagara
}

\begin{abstract}
In 2003 wayang was recognized by UNESCO as a global masterpiece as well as an intangible cultural heritage. Sundanese culture recognizes the legacy of wayang golek originating from the West Java region, and is usually realized through the display of props or puppets as a dualistic depiction of Javanese minds. In puppet show there are characters and characters that are played, but usually people are more familiar with the character of the Cepot who is considered as a entertainer and identity of the Sundanese. The purpose of this study was to see the meaning of the Cepot figure in puppet show art towards millennial Sundanese people and generation $Z$. The theories used in this study were the theory of communication, puppetry, and the concept of meaning. In this case the data obtained through the results of observations and interviews. The conclusion in this study is that the Sundanese generation of generation millennial and generation $Z$ considers the puppet show as an important art, but no longer as the main consumption. Besides that, there is a loss of elements from the Cepot character in the puppet show, even the Sundanese people consider the Cepot figure only as an entertaining figure.
\end{abstract}

Keywords: art, cepot, meaning, sundanese society, wayang golek.

\begin{abstract}
Abstrak
Pada tahun 2003, wayang diakui oleh UNESCO sebagai karya agung dunia sekaligus warisan budaya tak benda. Budaya Sunda mengenal warisan wayang golek yang berasal dari wilayah Jawa Barat, dan biasanya direalisasikan melalui pertunjukan alat peraga atau boneka sebagai penggambaran alam pikiran orang Jawa yang dualistik. Dalam kesenian wayang golek terdapat tokoh dan karakter yang dimainkan, namun biasanya masyarakat lebih mengenal tokoh si Cepot yang dianggap sebagai penghibur dan jati diri orang Sunda. Tujuan penelitian ini adalah untuk melihat makna tokoh si Cepot dalam kesenian wayang golek terhadap masyarakat Sunda milenial dan generasi Z. Teori yang digunakan dalam penelitian ini adalah teori komunikasi, wayang, dan konsep makna. Dalam hal ini data yang diperoleh melalui hasil dari observasi dan wawancara. Kesimpulan dalam penelitian ini adalah bahwa masyarakat Sunda generasi milenial dan generasi $\mathrm{Z}$ menganggap kesenian wayang golek sebagai suatu kesenian yang penting, namun bukan lagi sebagai konsumsi utama. Selain itu adanyaunsur dari tokoh si Cepot yang hilang dalam wayang golek. Bahkan masyarakat Sunda menganggap tokoh si Cepot hanya sebagai tokoh penghibur.
\end{abstract}

Kata Kunci: cepot, kesenian, makna, masyarakat sunda, wayang golek.

\section{Pendahuluan}

Wayang merupakan suatu bentuk kesenian budaya bangsa Indonesia di wilayah Jawa. Menurut Dr. G.A.J. Hazeu kata wayang berkaitan dengan kata "hyang" yang berarti "leluhur" (Sutardjo, 2008). Sri Mulyono menjelaskan bahwa Wayang atau Hewayang adalah bergaul dengan bayang-bayang atau mempertunjukan bayangan 
(Suharyono, 2005). Menurut Sunarto (1979), awal timbulnya wayang sangat erat kaitannya dengan pemujaan roh leluhur yang disebut hyang. Oleh sebab itu untuk menghormati agar selalu dilindungi, maka dilakukan berbagai cara salah satunya ialah melakukan pertunjukan bayang-bayang yang dilakukan terus menerus sehingga menjadi suatu tradisi oleh masyarakat agraris (Anggoro, 2018). Kesenian wayang biasanya direalisasikan melalui pertunjukan simbolik dengan alat peraga atau boneka sebagai penggambaran alam pikiran orang Jawa yang dualistik (Yuflih, 2015). Pada tahun 2003 wayang diakui oleh UNESCO sebagai karya agung dunia sekaligus warisan budaya tak benda. Dalam hal ini menurut Wintala (2014) wayang memiliki berbagai macam ragam, yaitu wayang beber, wayang wong, wayang klitik, wayang kulit, dan wayang golek (Sabila, 2018).

Wayang golek merupakan jenis pertunjukan tradisional yang telah menjadi bagian dari jati diri orang Sunda (Rosyadi, 2009). Kesenian ini merupakan pertunjukan yang hidup dan berkembang di wilayah budaya Sunda, dan dipandang sebagai salah satu bentuk tontonan dari berbagai lapisan masyarakat yang kental dengan nilai-nilai kerakyatannya (Cahya, 2016). Menurut Ganjar Kurnia (2013) suku bangsa Sunda merupakan suku bangsa terbesar kedua di Indonesia, namun eksistensi dari suku bangsa yang besar tersebut secara perlahan semakin hilang seiring dengan masuknya budaya-budaya luar serta perkembangan zaman. Disamping itu terdapat pengelompokan atau teori generasi yang muncul dengan pandangan-pandangan atau pemahaman dalam pembagian kelompok generasi.

Tabel 1. Pengelompokan Generasi Menurut National Chamber Fondation

\begin{tabular}{|c|c|}
\hline \multicolumn{1}{|c|}{ Jenis Generasi } & Lahir \\
\hline GI Generation & $1901-1924$ \\
\hline Silent Generation & $1925-1946$ \\
\hline Baby Boom Generation & $1946-1964$ \\
\hline Generation X & $1965-1979$ \\
\hline Millenial Generation & $1980-1999$ \\
\hline Generation Z & $2000-$ \\
\hline
\end{tabular}

Sumber: The Millennial Generation Research Review, NFC (Kementerian Pemberdayaan Perempuan dan Perlindungan Anak, 2018)

Dalam wayang golek terdapat peran atau tokoh yang sering dimainkan oleh dalang. Salah satunya ialah si Cepot yang mempunyai nama Astrajingga dengan dua suku kata, yaitu sastra yang berarti tulisan, dan jingga yang berarti merah sebagai lambang dari kelakuan yang buruk. Namun dibalik warna merahnya, tokoh si Cepot memiliki makna, nilai, dan gambaran yang bersifat berani. Hal ini ditambah dengan karakternya yang konyol dan selalu membuat jengkel (Nurhidayat, 2018). Dalam kaitannya dengan komunikasi, tentunya wayang tidak dapat dipisahkan. Hal ini dapat dilihat dari sisi pertunjukan wayang yang dimainkan dengan cerita-cerita yang berfungsi sebagai sarana hiburan bagi masyarakat (Rosyadi, 2009). Selain sebagai media hiburan, wayang juga menjadi sebuah seni pertunjukan yang merupakan bagian dari komunikasi simbolik perilaku manusia dalam praktik agama dan budaya (Seramasara, 2019).

Menurut Edward T. Hall (1981) kebudayaan adalah komunikasi dan komunikasi adalah kebudayaan (Liliweri, 2009). Kebudayaan merupakan keseluruhan perilaku yang dipelajari sekelompok orang secara umum untuk menerangkan tradisi kehidupan yang diwariskan oleh generasi ke generasi lain. Dalam hal ini, kebudayaan 
merupakan komunikasi simbolis atau makna yang dipelajari menyangkut keterampilan kelompok, pengetahuan, sikap, dan motif (Liliweri, 2009). Alasan penulis meneliti mengenai tokoh wayang golek si Cepot pada masyarakat Sunda milenial dan generasi $\mathrm{Z}$ adalah karena melihat peradaban zaman dengan masuknya budaya luar sehingga penulis ingin melihat pandangan mengenai kesenian wayang golek khususnya pada karakter si Cepot yang lucu, dan seringkali dipakai sebagai cenderamata wilayah Jawa Barat.

Rumusan masalah dibuat berkaitan dengan masalah yang akan diteliti oleh penulis, yaitu bagaimana makna wayang golek si Cepot pada masyarakat Sunda milenial dan generasi Z? Tujuan penelitian ini untuk mengetahui secara mendalam mengenai makna wayang golek si Cepot pada masyarakat Sunda milenial dan generasi Z. Dalam hal ini, makna referensial pada wayang golek si Cepot, makna significance pada wayang golek si Cepot, dan makna intensional pada wayang golek si Cepot.

\section{Metode Penelitian}

Menurut Kirk dan Miller (1986), istilah penelitian kualitatif pada mulanya bersumber pada pengamatan kualitatif yang bertentangan dengan penelitian kuantitatif. Dalam kajian terhadap penelitian kualitatif, Bogdan dan Taylor (1975) mendefinisikan penelitian dengan metodologi kualitatif sebagai prosedur dengan penelitian yang menghasilkan data deskriptif berupa kata-kata secara tertulis maupun lisan berdasarkan orang-orang serta perilaku yang dapat diamati (Moleong, 2018). Hal ini turut dikemukakan oleh Kriyantono (2009) bahwa penelitian kualitatif merupakan penelitian yang tidak menggunakan prosedur statistik (Sinta, 2018).

Penelitian ini memiliki tujuan untuk mengetahui pandangan masyarakat Sunda milenial dan generasi $\mathrm{Z}$ terhadap karakter tokoh si Cepot. Dalam penelitian ini penulis menggunakan jenis penelitian kualitatif dengan pendekatan studi kasus yang merupakan sebuah model penelitian yang memfokuskan eksplorasi "sistem terbatas" (bounded system) terhadap satu kasus, khusus maupun pada sebagian kasus secara terperinci dengan penggalian data secara mendalam (Creswell, 2015).

Penulis memilih subyek penelitian pelajar dan mahasiswa (Sekolah Menengah Pertama - Universitas) yang merupakan kriteria dari subyek penelitian sebagai masyarakat yang tergolong milenial dan generasi Z. Sedangkan obyek penelitian yang diambil oleh peneliti adalah Wayang Golek tokoh si Cepot. Teknik pengumpulan data yang digunakan dalam penelitian ini adalah wawancara dengan informan-informan yang menjadi kriteria penulis. Selain itu penulis juga menggunakan teknik observasi, studi kepustakaan, dan penelusuran data online yang menambah dan memperkuat penelitian ini.

Wawancara merupakan percakapan dengan maksud tujuan tertentu yang dilakukan oleh dua pihak yaitu, pewawancara (interviewer) yang mengajukan pertanyaan, dan terwawancara (interviewee) yang memberikan jawaban atas pertanyaan tersebut (Moleong, 2018). Menurut Sutrisno Hadi (1986) anggapan yang perlu dipegang oleh peneliti dalam menggunakan metode wawancara dan angket adalah: 1) subjek (responden) adalah orang yang paling tahu mengenai dirinya sendiri, 2) apa yang dinyatakan oleh subyek kepada peneliti adalah benar dan dapat dipercaya, 3) interpretasi subyek tentang pertanyaan-pertanyaan yang diajukan peneliti kepadanya adalah sama dengan maksud oleh peneliti (Sugiyono, 2011). 
Analisis data adalah sebuah kegiatan untuk mengatur, mengurutkan, mengelompokkan, memberi kode atau tanda, dan mengkategorikannya suatu temuan yang diperoleh berdasarkan fokus atau masalah yang ingin dijawab. Menurut Miles dan Hubernam (1992) tiga tahapan utama analisis data yaitu: 1) mereduksi data, 2) memaparkan data, 3) penarikan simpulan (Gunawan, 2014). Menurut Bogdan (1982) analisis data kualitatif merupakan upaya yang dilakukan dengan jalan yang bekerja dengan ata, mengorganisasikan data, memilah-milahnya menjadi satuan yang dapat dikelola, mensintesiskannya, mencari dan menemukan pola, menemukan apa yang penting dan apa yang dipelajari, serta memutuskan apa yang dapat diceritakan kepada orang lain (Moleong, 2018). Dalam penelitian yang digunakan maka terdapat teknik pemeriksaan yang digunakan, dengan demikian pada penelitian ini melakukan pemeriksaan dengan pendekatan tringulasi dalam pengujian kredibilitas diartikan sebagai pengecekan data dari berbagai sumber dengan berbagai cara dan waktu. (Sugiyono, 2011).

\section{Hasil Temuan dan Diskusi}

Berdasarkan data hasil temuan yang dilakukan dengan wawancara dan observasi, maka penulis menemukan bahwa:

a. Masyarakat masih menganggap kesenian Wayang Golek sebagai kesenian yang penting.

Secara umum wayang golek merupakan salah satu kesenian Indonesia yang berkembang di Jawa Barat atau Sunda. Berkembangnya zaman dengan masuknya budaya-budaya asing tidak membuat kesenian ini ditinggalkan, karena dalam hal ini kesenian wayang golek masih dianggap penting sebagai warisan budaya Indonesia khususnya Sunda.

b. Kesenian Wayang Golek bukan menjadi konsumsi utama bagi masyarakat Sunda Milenial dan Generasi Z

Seiring perkembangan zaman dengan masuknya budaya-budaya luar dan teknologi yang semakin canggih, maka berdasarkan hasil observasi, peneliti menemukan bahwa kesenian atau pertunjukan wayang golek bukan menjadi konsumsi yang utama bagi masyarakat Sunda millennial dan generasi Z. Masyarakat Sunda milenial dan generasi $\mathrm{Z}$ memiliki fokus terhadap gadget sebagai bagian dari peradaban zaman.

c. Makna Wayang Golek tokoh si Cepot pada masyarakat Sunda Generasi Millenial dan Z.

Secara umum kesenian wayang golek merupakan kesenian yang berkembang di wilayah Jawa Barat atau Sunda. Tentunya dalam kesenian wayang golek terdapat tokoh-tokoh yang dimainkan, salah satu tokoh yang dimainkan adalah si Cepot. Tokoh yang memiliki ciri khas dengan warnanya yang merah, giginya yang maju dan bibir yang tebal memiliki makna, nilai, dan gambaran yang bersifat berani (Nurhidayat, 2018). Biasanya masyarakat Sunda menganggap tokoh si Cepot sebagai karakter yang konyol dan lucu. Oleh sebab itu, peneliti melakukan penjabaran terkait makna tokoh si Cepot dalam wayang golek sebagai berikut:

1) Makna Referensial

Makna referensial didefinisikan sebagai makna satu kata (lambang) yang diartikan sebagai objek, pikiran, gagasan, dan konsep yang dirujuk terhadap kata tersebut. Menurut Ogden dan Richard (1946), proses 
pemberian makna disebut sebagai rujukan atau referen (reference process), hal ini terjadi apabila kita menghubungkan lambang dengan hal yang ditunjukan pada lambang tersebut. (Rakhmat, 2012). Berdasarkan hasil wawancara, maka tokoh si Cepot memiliki beberapa rujukan yaitu, sebagai kesenian wayang golek, sebagai jati diri orang Sunda, sebagai sejarah dan merupakan rumah makan.

2) Makna Significance

Menurut analisa penulis, berdasarkan hasil wawancara, maka dalam hal ini kata atau karakter si Cepot memiliki berbagai macam rujukan yang dimilikinya, antara lain hanya sebagai kesenian wayang golek, sebagai jati diri orang Sunda, sebagai sejarah dan merupakan rumah makan. Makna ini didefinisikan sebagai istilah yang menunjukan arti, dihubungkan dengan konsep-konsep lain. Dalam hal ini, kata-kata menjadi tidak berarti karena adanya penemuan-penemuan baru sehingga menunjukan adanya kesalahan pada konsep yang lama (Rakhmat, 2012). Penulis menghubungkan makna tokoh si Cepot dalam kesenian wayang golek dengan konsep-konsep yang didapat melalui hasil wawancara, yaitu konsep yang lama seperti hiburan dan praktik agama digantikan sebagai sebatas hiburan semata dan bagian dalam sejarah budaya.

3) Makna Intentional makna intentional didefinisikan sebagai makna yang dimaksud merupakan seorang pemakai simbol. Dalam hal ini, makna tidak dapat divalidasi secara empiris atau dicarikan rujukannya, karena makna ini hanya terdapat pada pikiran orang yang dimilikinya sendiri saja. Makna ini juga diulas dengan menggunakan makna konotasi atau makna perorangan (Rakhmat, 2017). Oleh sebab itu peneliti menganalisa terdapat beberapa makna yang ada dipikiran orang yang dimilikinya dengan terbentuk berdasarkan makna referensial. Berdasarkan hasil wawancara yang didapat, maka masyarakat mengartikan tokoh si Cepot sebagai penyemangat, lambang kota Bandung, dan rumah makan.

\section{Simpulan}

Penulis menyimpulkan beberapa kesimpulan yang menjadi hasil dan temuan penelitian penulis sebagai berikut:

a. Masuknya budaya-budaya dari luar dan adanya teknologi yang semakin canggih, tidak mengubah pernyataan masyarakat Sunda khususnya generasi milenial dan generasi $\mathrm{Z}$ akan pentingnya kesenian wayang golek yang harus dilestarikan.

b. Pentingnya kesenian wayang golek bagi masyarakat Sunda terutama bagi generasi milenial dan generasi $\mathrm{Z}$ tidak membuat kesenian wayang golek menjadi konsumsi utama di zaman sekarang ini, ditambah dengan adanya gadget yang membuat peralihan fokus kepada gadget masing-masing.

c. Makna tokoh si Cepot dalam wayang golek memiliki beberapa rujukan bagi masyarakat Sunda milenial dan generasi Z, yaitu adanya anggapan bahwa si Cepot hanya bagian dari kesenian wayang semata. Beberapa menganggap sebagai bagian dari jati diri orang Sunda, serta adanya anggapan yang berkaitan dengan sejarah dan rumah makan. 
d. Makna tokoh si Cepot dalam wayang golek sebenarnya memiliki kaitan erat dengan hiburan dan praktek agama, namun melihat perkembangan zaman yang membuat pengaruh dalam kesenian dan budaya. Berdasarkan hasil observasi dan wawancara, maka dapat dikatakan ada hilangnya satu atau beberapa makna yang membuat tokoh si Cepot dalam wayang golek bagi masyarakat Sunda milenial dan generasi $\mathrm{Z}$ hanya dianggap sebagai hiburan semata.

e. Makna lainnya terhadap tokoh si Cepot bagi masyarakat Sunda milenial dan generasi $\mathrm{Z}$ beranggapan bahwa si Cepot merupakan tokoh yang berwarna merah, bodoh, lucu, penyemangat, kasar, nama rumah makan dan merupakan simbol dari kota Bandung.

\section{Ucapan Terima Kasih}

Puji dan syukur penulis ucapkan kepada Tuhan Yang Maha Esa, karena atas segala berkat dan karunia-Nya telah memberikan penulis kesehatan secara jasmani dan rohani sehingga dapat melaksanakan kegiatan penelitian untuk menyelesaikan, serta menyusun laporan dengan maksimal. Penulis mengucapkan terima kasih sebesarbesarnya kepada seluruh yang selalu memberikan bantuan, dukungan, bahkan saran yang diberikan sampai dengan terbitnya publikasi hasil penelitian ini.

\section{Daftar Pustaka}

Bungin, Burhan. (2010). Metode Penelitian Kualitatif. Jakarta: Raja Grafindo Persada. Creswell, John W. (2015). Penelitian Kualitatif dan Desain Reset. Yogyakarta: Pustaka Pelajar.

Gunawan, Imam. (2014). Metode Penelitian Kualitatif Teori \& Praktik. Jakarta: Bumi Aksara.

Idrus, Muhammad. (2009). Metode Penelitian Ilmu Sosial Pendekatan Kualitatif dan Kuantitatif. Jakarta: Erlangga.

Liliweri, Alo. (2009). Makna Budaya dalam Komunikasi Antarbudaya.Yogyakarta : LKiS .

Moleong, Lexy J. (2018). Metodologi Penelitian Kualitatif. Bandung: Remaja Rodakarya.

Rakhmat, Jalaluddin. (2012). Psikologi Komunikasi. Bandung: Remaja Rosdakarya.

Sugiyono. (2011). Metode Penelitian Pendidikan Pendekatan Kuantitatif, Kualitatif, dan $R \& D$. Bandung: Alfabeta.

Suharyono, Bagyo. (2005). Wayang Beber Wonosari. Solo: Bina Citra Pustaka.

Anggoro, Bayu. (2018). Wayang dan Seni Pertunjukan: Kajian Sejarah Perkembangan Seni Wayang di Tanah Jawa sebagai Seni Pertunjukan dan Dakwah. Diakses pada 23 Agustus 2019, dan terarsip di: http://jurnal.uinsu.ac.id/index.php/juspi/article/view/1679/1812

Cahya. (2016). Nilai, Makna, dan Simbol Dalam Pertunjukan Wayang Golek Sebagai Representasi Media Pendidikan Budi Pekert. Diakses pada 23 Agustus 2019, dan Terarsip

di: https://jurnal.isbi.ac.id/index.php/panggung/article/download/170/220.

Nurhidayat, Feri Sandria. (2016). Representasi Warna Merah Pada Wayang Golek si Cepot. Diakses pada 24 Agustus 2019, dan terarsip di: http://ojs.uninus.ac.id/index.php/ProListik/article/view/133 
Paramita, Sinta. (2018). Pergeseran Makna Budaya Ondel-Ondel Pada Masyarakat Betawi Modern. Diakses pada 10 Oktober 2019, terarsip di: https://journal.untar.ac.id/index.php/baktimas/article/view/1888/1050

Rosyadi. (2009). Wayang Golek Dari Seni Pertunjukan Ke Seni Kriya (Studi Tentang Perkembangan Fungsi Wayang Golek di Kota Bogor). Diakse pada 23 Agustus 2019, dan terarsip di : http://ejurnalpatanjala.kemdikbud.go.id/patanjala/index.php/patanjala/article/ view/239/187

Sabila, Shafira. (2018). Strategi Humas Gerbang Kreasi Pemuda Cijahe (GKPC) Dalam Melestarikan Kesenian Tradisional Wayang Dalam Bentuk Wayang Bambu di Kelurahan Curug Mekar Kota Bogor. Diakses pada 24 Agustus 2019, dan terarsip di: https://library.moestopo.ac.id/index.php?p=fstreampdf\&fid=2144\&bid=40753.

Seramasara, I Gusti Ngurah. (2019). Wayang Sebagai Media Komunikasi Simbolik Perilaku Manusia Dalam Praktek Budaya dan Agama di Bali. Diakses pada tanggal 24 Agustus 2019, dan terarsip di : https://jurnal.isidps.ac.id/index.php/mudra/article/view/640/347

Sutomo. (2015). Konteks, Referensi, dan Makna: Kajian Semantik. Diakses pada 1 Oktober 2019. di: https://www.unisbank.ac.id/ojs/index.php/fbib1/article/view/3748.

Yuflih, Wildan. (2015). Perilaku Komunikasi Dalang Wayang Kulit Dalam Memberikan Pesan Moral Kepada Penontonya di Kota Bandung. Diakses pada 24 Agustus 2019, dan terarsip di: https://elib.unikom.ac.id/download.php?id=272530.

Ganjar Kurnia. (2013). Kurang, Kesadaran Masyarakat Sunda Menjaga Budaya Sunda. Diakses pada 24 Agustus 2019, yang terarsip di: http://www.unpad.ac.id/2013/01/kurang-kesadaran-masyarakat-sundamenjaga-budaya-sunda/

Kementerian Perempuan dan Perlindungan Anak. (2018). Profil Generasi Milenial Indonesia. Diakses pada 13 Januari 2020, yang terarsip di: https://www.kemenpppa.go.id/lib/uploads/list/9acde-buku-profil-generasimilenia.pdf 